\title{
Crystallographic and Magnetic Properties of Co, Zn, Ni-Zn Substituted Nano-size Manganese Ferrites Synthesized by Sol-gel Method
}

\author{
Kwang Mo Noh', Young Bae Lee², Woo Hyun Kwon', Jeoung Yun Kang', \\ Won-Ok Choi ${ }^{1}$, and Kwang Pyo Chae ${ }^{1 *}$ \\ ${ }^{1}$ Department of Nano Science and Mechatronics Engineering, Nanotechnology Research Center, Konkuk University, \\ Chungju 27478, Korea \\ ${ }^{2}$ Department of Physics, Hanzhong University, Donghae 25800, Korea
}

(Received 13 July 2016, Received in final form 29 August 2016, Accepted 31 August 2016)

\begin{abstract}
Cobalt-, zinc-, and nickel-zinc-substituted nano-size manganese ferrite powders, $\mathrm{MnFe}_{2} \mathrm{O}_{4}, \mathrm{Mn}_{0.8} \mathrm{Co}_{0.2} \mathrm{Fe}_{2} \mathrm{O}_{4}$, $\mathrm{Mn}_{0.8} \mathrm{Zn}_{0.2} \mathrm{Fe}_{2} \mathrm{O}_{4}$ and $\mathrm{Mn}_{0.8} \mathrm{Ni}_{0.1} \mathrm{Zn}_{0.1} \mathrm{Fe}_{2} \mathrm{O}_{4}$, were fabricated using a sol-gel method, and their crystallographic and magnetic properties were subsequently studied. The $\mathrm{MnFe}_{2} \mathrm{O}_{4}$ ferrite powder annealed at temperatures above $523 \mathrm{~K}$ exhibited a spinel structure, and the particle size increased as the annealing temperature increased. All ferrites annealed at $773 \mathrm{~K}$ showed a single spinel structure, and the lattice constants and particle size decreased with the substitution of $\mathrm{Co}, \mathrm{Zn}$, and $\mathrm{Ni}-\mathrm{Zn}$. The Mössbauer spectrum of the $\mathrm{MnFe}_{2} \mathrm{O}_{4}$ ferrite powder annealed at $523 \mathrm{~K}$ only showed a doublet due to its superparamagnetic phase, and the Mössbauer spectra of the $\mathrm{MnFe}_{2} \mathrm{O}_{4}, \mathrm{Mn}_{0.8} \mathrm{Co}_{0.2} \mathrm{Fe}_{2} \mathrm{O}_{4}$, and $\mathrm{Mn}_{0.8} \mathrm{Zn}_{0.2} \mathrm{Fe}_{2} \mathrm{O}_{4}$ ferrite powders annealed at $773 \mathrm{~K}$ could be fitted as the superposition of two Zeeman sextets due to the tetrahedral and octahedral sites of the $\mathrm{Fe}^{3+}$ ions. However, the Mössbauer spectrum of the $\mathrm{Mn}_{0.8} \mathrm{Ni}_{0.1} \mathrm{Zn}_{0.1} \mathrm{Fe}_{2} \mathrm{O}_{4}$ ferrite powder annealed at $773 \mathrm{~K}$ consisted of two Zeeman sextets and one quadrupole doublet due to its ferrimagnetic and paramagnetic behavior. The area ratio of the Mössbauer spectra could be used to determine the cation distribution equation, and we also explained the variation in the Mössbauer parameters by using this cation distribution equation, the superexchange interaction and the particle size. Relative to pure $\mathrm{MnFe}_{2} \mathrm{O}_{4}$, the saturation magnetizations and coercivities were larger in $\mathrm{Mn}_{0.8} \mathrm{Co}_{0.2} \mathrm{Fe}_{2} \mathrm{O}_{4}$ and smaller in $\mathrm{Mn}_{0.8} \mathrm{Zn}_{0.2} \mathrm{Fe}_{2} \mathrm{O}_{4}$, and $\mathrm{Mn}_{0.8} \mathrm{Ni}_{0.1} \mathrm{Zn}_{0.1} \mathrm{Fe}_{2} \mathrm{O}_{4}$. These variations could be explained using the site distribution equations, particle sizes and magnetic moments of the substituted ions.
\end{abstract}

Keywords : substituted manganese ferrite, sol-gel method, Mössbauer spectroscopy, saturation magnetization, coercivity

\section{Introduction}

Ferrites are important materials because they are relatively inert and their properties can be tailored via chemical manipulations. Ferrites have a spinel crystal structure (space group $\mathrm{Fd} 3 \mathrm{~m}$ ) in which the $\mathrm{O}^{2-}$ ion lattice forms areas with tetrahedral and octahedral local symmetry, and these are respectively referred to as $\mathrm{A}$ and $\mathrm{B}$ sites in the spinel formular $\mathrm{AB}_{2} \mathrm{O}_{4}$. For example, manganese ferrite, $\mathrm{MnFe}_{2} \mathrm{O}_{4}$, has a spinel crystal structure and has been used extensively in microwave and magnetic recording applications. In a normal spinel structure, di-

CThe Korean Magnetics Society. All rights reserved.

*Corresponding author: Tel: +82-43-840-3623

Fax: +82-43-851-4169, e-mail: kpchae@kku.ac.kr valent ions $\left(\mathrm{Mn}^{2+}\right)$ only occupy the A sites, and trivalent ions $\left(\mathrm{Fe}^{3+}\right)$ only occupy the $\mathrm{B}$ sites. In an inverse spinel structure, divalent ions occupy half of the $\mathrm{B}$ sites, and trivalent ions occupy the rest of the $\mathrm{B}$ sites and all A sites. In $\mathrm{MnFe}_{2} \mathrm{O}_{4}$ prepared at high temperatures $(>1,173 \mathrm{~K})$, $20 \%$ of the $\mathrm{Mn}^{2+}$ ions migrate from the A to $\mathrm{B}$ sites, which means that $\mathrm{MnFe}_{2} \mathrm{O}_{4}$ may be characterized as a mixture of normal and inverse spinel ferrite [1-3]. Cobalt ferrite, $\mathrm{CoFe}_{2} \mathrm{O}_{4}$, has a cubic spinel structure and has been extensively studied due to its interesting magnetic properties. Cobalt ferrite is basically an inverse spinel for which the corrected cation distribution becomes $\left(\mathrm{Co}_{0.1} \mathrm{Fe}_{0.9}\right)\left[\mathrm{Co}_{0.9} \mathrm{Fe}_{1.1}\right] \mathrm{O}_{4}$. The degree of inversion thus depends on its thermal history. Cobalt ferrite has been regarded as a competitive alternative for high-density magnetic recording media due to its high coercivity, 
moderate saturation magnetization, remarkable chemical stability, and mechanical hardness [4, 5]. Zinc ferrite, $\mathrm{ZnFe}_{2} \mathrm{O}_{4}$, has a normal spinel structure, where the diamagnetic $\mathrm{Zn}^{2+}$ ions occupy only A sites, and as a result, all $\mathrm{Fe}^{3+}$ ions are in $\mathrm{B}$ sites and are coupled between each other via superexchange pathways through A sites. The $\mathrm{B}-\mathrm{B}$ interactions are very weak, and normal spinel $\mathrm{ZnFe}_{2} \mathrm{O}_{4}$ shows long-range antiferromagnetic ordering at $T_{N}=9-11 \mathrm{~K}$. Nickel ferrite, $\mathrm{NiFe}_{2} \mathrm{O}_{4}$, has an inverse spinel structure in which the A sites are occupied by $\mathrm{Fe}^{3+}$ ions and the $\mathrm{B}$ sites by $\mathrm{Fe}^{3+}$ and $\mathrm{Ni}^{2+}$ ions. Ni-Zn ferrite has a mixed spinel structure in which the $\mathrm{A}$ sites are occupied by $\mathrm{Zn}^{2+}$ and $\mathrm{Fe}^{3+}$ and the $\mathrm{B}$ sites by $\mathrm{Ni}^{2+}$ and $\mathrm{Fe}^{3+}$ ions [6-8]. Several approaches have been exploited to obtain more usable magnetic materials, including adjusting the substitution ions and ratio through the use of various synthesis methods. One of the advantages of using the sol-gel method is that a lower annealing temperature can be used to enable the growth of smaller grained powders. Thus, the sol-gel method can provide a multi-component oxide with a homogeneous composition, and it has been employed to prepare many high purity oxide powders, including some products with spinel-type structures $[9,10]$. Recently we also studied nickel substituted effects on Co, Mn, MnZn ferrites synthesize by sol-gel method [11, 12]. In this study, the sol-gel method is used to synthesize the magnetic and nonmagnetic ion substituted manganese ferrites. The cobalt-, zinc-, and nickel-zinc-substituted nano-size manganese ferrite powders - $\mathrm{MnFe}_{2} \mathrm{O}_{4}, \mathrm{Mn}_{0.8} \mathrm{Co}_{0.2} \mathrm{Fe}_{2} \mathrm{O}_{4}, \mathrm{Mn}_{0.8} \mathrm{Zn}_{0.2} \mathrm{Fe}_{2} \mathrm{O}_{4}$ and $\mathrm{Mn}_{0.8} \mathrm{Ni}_{0.1} \mathrm{Zn}_{0.1} \mathrm{Fe}_{2} \mathrm{O}_{4}$ - and their crystallographic and magnetic properties were compared via $\mathrm{X}$-ray diffractometry (XRD), field emission scanning electron microscopy (FESEM), Mössbauer spectroscopy, and vibrating sample magnetometry (VSM).

\section{Experiment}

$\mathrm{MnFe}_{2} \mathrm{O}_{4}, \mathrm{Mn}_{0.8} \mathrm{Co}_{0.2} \mathrm{Fe}_{2} \mathrm{O}_{4}, \mathrm{Mn}_{0.8} \mathrm{Zn}_{0.2} \mathrm{Fe}_{2} \mathrm{O}_{4}$, and $\mathrm{Mn}_{0.8^{-}}$ $\mathrm{Ni}_{0.1} \mathrm{Zn}_{0.1} \mathrm{Fe}_{2} \mathrm{O}_{4}$ ferrite samples were synthesized using the sol-gel method. Measured amounts of $\mathrm{Mn}\left(\mathrm{NO}_{3}\right)_{2} \cdot \mathrm{H}_{2} \mathrm{O}$, $\mathrm{Zn}\left(\mathrm{NO}_{3}\right)_{2} \cdot 6 \mathrm{H}_{2} \mathrm{O}, \quad \mathrm{Ni}\left(\mathrm{NO}_{3}\right)_{2} \cdot 6 \mathrm{H}_{2} \mathrm{O}$, and $\mathrm{Fe}\left(\mathrm{NO}_{3}\right) \cdot 9 \mathrm{H}_{2} \mathrm{O}$ were first dissolved in 2-Methoxyethanol with an ultrasonic cleaner for 30-50 min. The solution was refluxed at $353 \mathrm{~K}$ for $12 \mathrm{~h}$ in order to gel, and was dried at $363 \mathrm{~K}$ in a dry oven for $24 \mathrm{~h}$. The dried powder samples were ground and annealed at various temperatures for $6 \mathrm{~h}$, and all heat-treatment processes were carried out in an $\mathrm{N}_{2}$ atmosphere to prevent the oxidation of the anion ions. A large amount of $\mathrm{N}_{2}$ gas flowed early in the annealing process to remove the oxygen inside of the quartz tube and to emit the gas from the dry powder. In order to verify the purity, all samples were analyzed using an Xray diffractometer with Cuka $(1.54 \AA)$ radiation. The surface microstructure was observed using FESEM at room temperature, and the Mössbauer spectra of the powders were recorded with a ${ }^{57} \mathrm{Co}$ source in a constant acceleration mode to identify the magnetic phase of the ferrite powders. The saturation magnetization and the coercivity were then determined via VSM.

\section{Results and Discussion}

Figure 1 shows the X-ray diffraction patterns of the $\mathrm{MnFe}_{2} \mathrm{O}_{4}$ ferrite powders annealed at various temperatures, and the main peaks of the $\mathrm{MnFe}_{2} \mathrm{O}_{4}$ ferrite powders annealed above $523 \mathrm{~K}$ indicate a typical spinel structure. An increase in the annealing temperature leads to a sharpening of the major peak, which indicates the growth of the particle size of the spinel powders and an improvement in crystallization. The X-ray diffraction patterns of the $\mathrm{Mn}_{0.8} \mathrm{Co}_{0.2} \mathrm{Fe}_{2} \mathrm{O}_{4}, \mathrm{Mn}_{0.8} \mathrm{Zn}_{0.2} \mathrm{Fe}_{2} \mathrm{O}_{4}$, and $\mathrm{Mn}_{0.8} \mathrm{Ni}_{0.1^{-}}$ $\mathrm{Zn}_{0.1} \mathrm{Fe}_{2} \mathrm{O}_{4}$ ferrite powders annealed at $773 \mathrm{~K}$ are shown in Fig. 2. The X-ray diffraction measurement shows that all peaks are consistent with those of typical spinel structures of ferrite powders, and no extra peaks corresponding to any secondary phase could be observed. The lattice constant of the $\mathrm{MnFe}_{2} \mathrm{O}_{4}$ ferrite powder annealed at $773 \mathrm{~K}$ is $0.848 \mathrm{~nm}$. As shown in Table 1, with an increase

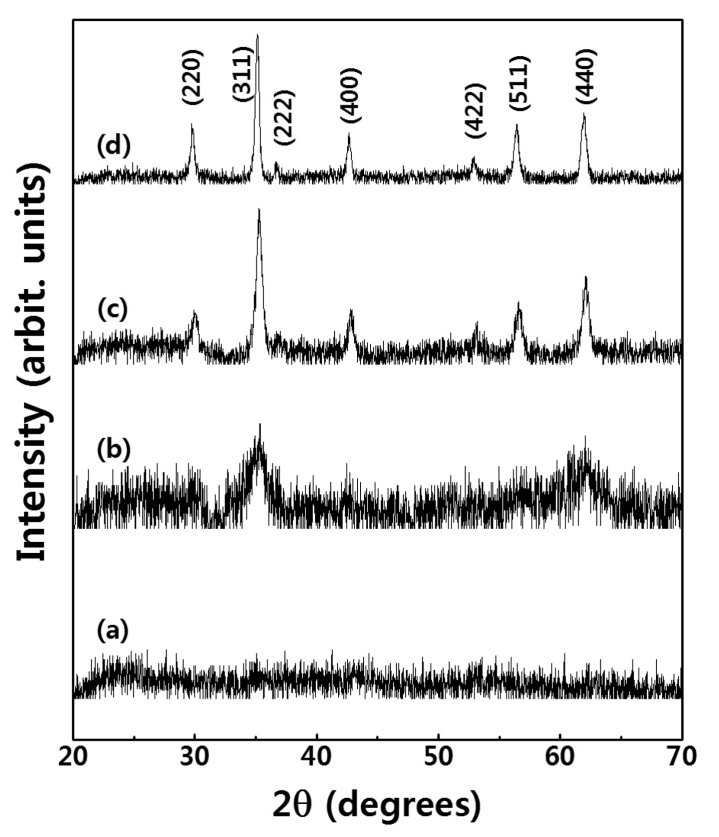

Fig. 1. X-ray diffraction patterns of $\mathrm{MnFe}_{2} \mathrm{O}_{4}$ ferrite powders annealed at various temperature: (a) $473 \mathrm{~K}$, (b) $523 \mathrm{~K}$, (c) 673 $\mathrm{K}$, and (d) $773 \mathrm{~K}$. 


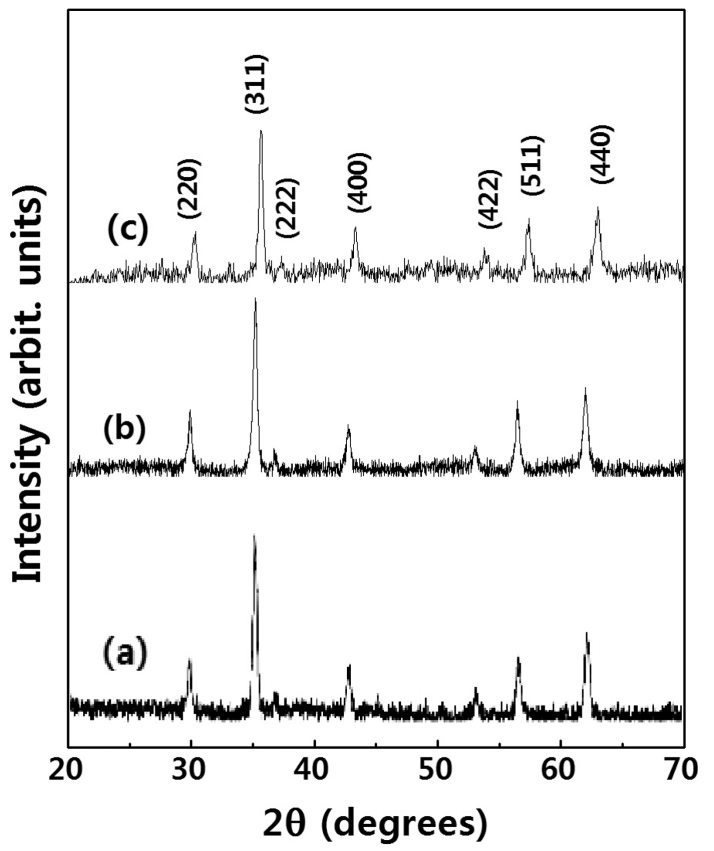

Fig. 2. X-ray diffraction patterns of ferrite powders annealed at $773 \mathrm{~K}$ : (a) $\mathrm{Mn}_{0.8} \mathrm{Co}_{0.2} \mathrm{Fe}_{2} \mathrm{O}_{4}$, (b) $\mathrm{Mn}_{0.8} \mathrm{Zn}_{0.2} \mathrm{Fe}_{2} \mathrm{O}_{4}$, and (c) $\mathrm{Mn}_{0.8} \mathrm{Ni}_{0.1} \mathrm{Zn}_{0.1} \mathrm{Fe}_{2} \mathrm{O}_{4}$.

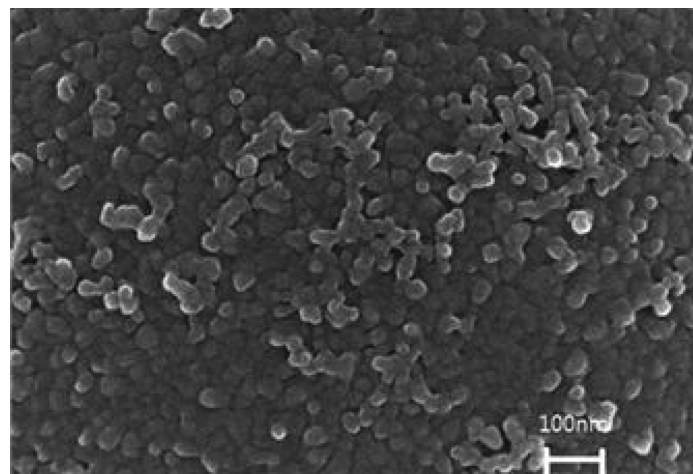

(a)

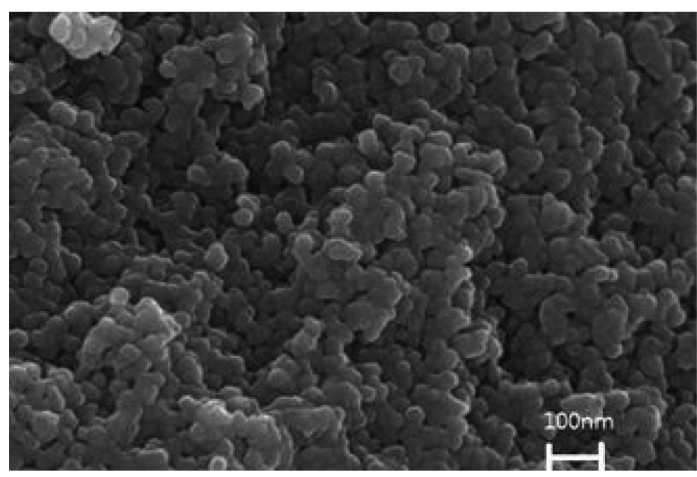

(c)
Table 1. Lattice constant and particle size of $\mathrm{MnFe}_{2} \mathrm{O}_{4}$, $\mathrm{Mn}_{0.8} \mathrm{Co}_{0.2} \mathrm{Fe}_{2} \mathrm{O}_{4}, \quad \mathrm{Mn}_{0.8} \mathrm{Zn}_{0.2} \mathrm{Fe}_{2} \mathrm{O}_{4}$, and $\mathrm{Mn}_{0.8} \mathrm{Ni}_{0.1} \mathrm{Zn}_{0.1} \mathrm{Fe}_{2} \mathrm{O}_{4}$ ferrite powders annealed at $773 \mathrm{~K}$.

\begin{tabular}{ccc}
\hline \hline Sample & Lattice constant $(\mathrm{nm})$ & Particle size $(\mathrm{nm})$ \\
\hline $\mathrm{MnFe}_{2} \mathrm{O}_{4}$ & 0.848 & 25.0 \\
$\mathrm{Mn}_{0.8} \mathrm{Co}_{0.2} \mathrm{Fe}_{2} \mathrm{O}_{4}$ & 0.843 & 40.0 \\
$\mathrm{Mn}_{0.8} \mathrm{Zn}_{0.2} \mathrm{Fe}_{2} \mathrm{O}_{4}$ & 0.847 & 76.3 \\
$\mathrm{Mn}_{0.8} \mathrm{Ni}_{0.1} \mathrm{Zn}_{0.1} \mathrm{Fe}_{2} \mathrm{O}_{4}$ & 0.841 & 90.9 \\
\hline
\end{tabular}

in substitution, the lattice constant of the four ferrites decreases from $0.848 \mathrm{~nm}$ (for $\mathrm{MnFe}_{2} \mathrm{O}_{4}$ ), to $0.843 \mathrm{~nm}$ (for $\mathrm{Mn}_{0.8} \mathrm{Co}_{0.2} \mathrm{Fe}_{2} \mathrm{O}_{4}$ ), to $0.847 \mathrm{~nm}$ (for $\mathrm{Mn}_{0.8} \mathrm{Zn}_{0.2} \mathrm{Fe}_{2} \mathrm{O}_{4}$ ), and to $0.841 \mathrm{~nm}$ (for $\mathrm{Mn}_{0.8} \mathrm{Ni}_{0.2} \mathrm{Zn}_{0.2} \mathrm{Fe}_{2} \mathrm{O}_{4}$ ). This can be explained using Vegard's law [13], which states that larger $\mathrm{Mn}^{2+}(0.091 \mathrm{~nm})$ ions are substituted by smaller $\mathrm{Co}^{2+}$ $(0.072 \mathrm{~nm}), \mathrm{Ni}^{2+}(0.069 \mathrm{~nm})$ and $\mathrm{Zn}^{2+}(0.082 \mathrm{~nm})$ ions, leading to a decrease in the lattice constants. The size of the particles was then determined from the broadening in the diffraction peak by using the Scherrer equation [14], $t$ $=(0.9 \lambda) /\left(B \cos \theta_{B}\right)$, where $\lambda$ represent the X-ray wavelength, $B$ is the half width of the (311) peak, and $\theta_{B}$ is the angle of the (311) peak. The particle size of the

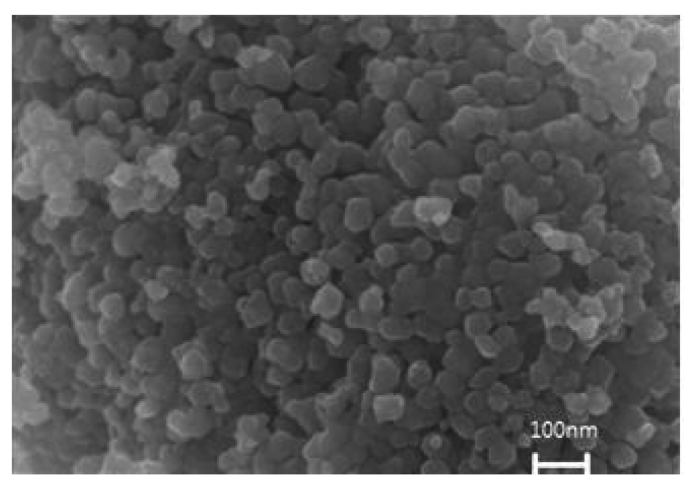

(b)

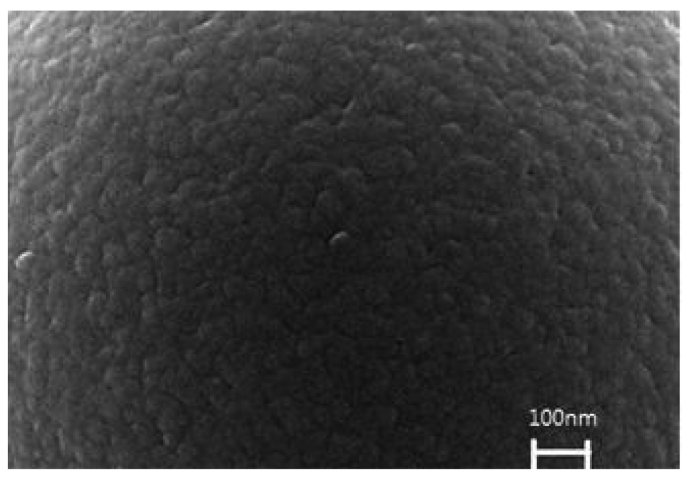

(d)

Fig. 3. SEM images $(100,000 \times)$ of ferrite powders annealed at $773 \mathrm{~K}$ : (a) $\mathrm{MnFe}_{2} \mathrm{O}_{4}$, (b) $\mathrm{Mn}_{0.8} \mathrm{Co}_{0.2} \mathrm{Fe}_{2} \mathrm{O}_{4},(\mathrm{c}) \mathrm{Mn}_{0.8} \mathrm{Zn}_{0.2} \mathrm{Fe}_{2} \mathrm{O}_{4}$, and (d) $\mathrm{Mn}_{0.8} \mathrm{Ni}_{0.1} \mathrm{Zn}_{0.1} \mathrm{Fe}_{2} \mathrm{O}_{4}$. 
$\mathrm{Mn}_{0.8} \mathrm{Zn}_{0.2} \mathrm{Fe}_{2} \mathrm{O}_{4}$ ferrite powders has been reported to increase with an increase in the annealing temperature from $20.7 \mathrm{~nm}(523 \mathrm{~K})$ to $45.7 \mathrm{~nm}(673 \mathrm{~K})$, and $76.3 \mathrm{~nm}$ (773 K) [15]. As shown in Table 1, the size of the particle of samples annealed at $773 \mathrm{~K}$ is larger than that of pure $\mathrm{MnFe}_{2} \mathrm{O}_{4}(25.0 \mathrm{~nm})$, such as with $40.0 \mathrm{~nm}$ for $\mathrm{Mn}_{0.8} \mathrm{Co}_{0.2} \mathrm{Fe}_{2} \mathrm{O}_{4}, 76.3 \mathrm{~nm}$ for $\mathrm{Mn}_{0.8} \mathrm{Zn}_{0.2} \mathrm{Fe}_{2} \mathrm{O}_{4}$, and 90.9 $\mathrm{nm}$ for $\mathrm{Mn}_{0.8} \mathrm{Ni}_{0.1} \mathrm{Zn}_{0.1} \mathrm{Fe}_{2} \mathrm{O}_{4}$ ferrite powders. This increase leads to a broadening of the major X-ray diffraction peak, that is, a growth in the smaller particle size of our spinel powders as well as an improved crystallization. All this also suggests that the manganese, manganese-cobalt, manganese-zinc and manganese-nickel-zinc ferrite powders synthesized via the sol-gel method have particle sizes ranging from $25.0 \mathrm{~nm}$ to $90.9 \mathrm{~nm}$, which are smaller when compare to those of powders obtained using ceramic and wet chemical methods. As shown in Fig. 3, the shape of the grains of the ferrites can be confirmed via FESEM with 100,000 times magnification. All samples have nano-size grains of a nearly homogeneous size, and the grain size increases with the cobalt, zinc, and nickel-zinc substitution.

The Mössbauer spectra measured at room temperature for the $\mathrm{MnFe}_{2} \mathrm{O}_{4}$ powder annealed at $523 \mathrm{~K}$, as shown in Fig. 4, is attributed to its paramagnetic behavior. This comes from having a small particle size, and superparamagnetic properties were confirmed with the low temperature Mössbauer spectra. The spectrum slowly changed from doublets at $180 \mathrm{~K}$ to Zeeman sextets below $50 \mathrm{~K}$. Figure 5 shows the Mössbauer spectra that were measured at room temperature for $\mathrm{MnFe}_{2} \mathrm{O}_{4}$, $\mathrm{Mn}_{0.8} \mathrm{Co}_{0.2} \mathrm{Fe}_{2} \mathrm{O}_{4}, \mathrm{Mn}_{0.8} \mathrm{Zn}_{0.2} \mathrm{Fe}_{2} \mathrm{O}_{4}$ and $\mathrm{Mn}_{0.8} \mathrm{Ni}_{0.1} \mathrm{Zn}_{0.1} \mathrm{Fe}_{2} \mathrm{O}_{4}$ ferrite powders annealed at $773 \mathrm{~K}$. The spectra for $\mathrm{MnFe}_{2} \mathrm{O}_{4}, \mathrm{Mn}_{0.8} \mathrm{Co}_{0.2} \mathrm{Fe}_{2} \mathrm{O}_{4}$, and $\mathrm{Mn}_{0.8} \mathrm{Zn}_{0.2} \mathrm{Fe}_{2} \mathrm{O}_{4}$ are fitted with two six-line subspectra, and these are assigned to the tetrahedral A site and octahedral B sites of a typical spinel crystal structure. As shown in Fig. 5 (d) the Mössbauer spectrum for $\mathrm{Mn}_{0.8} \mathrm{Ni}_{0.1} \mathrm{Zn}_{0.1} \mathrm{Fe}_{2} \mathrm{O}_{4}$ is fitted with two sextets and one doublet. The Mössbauer absorption

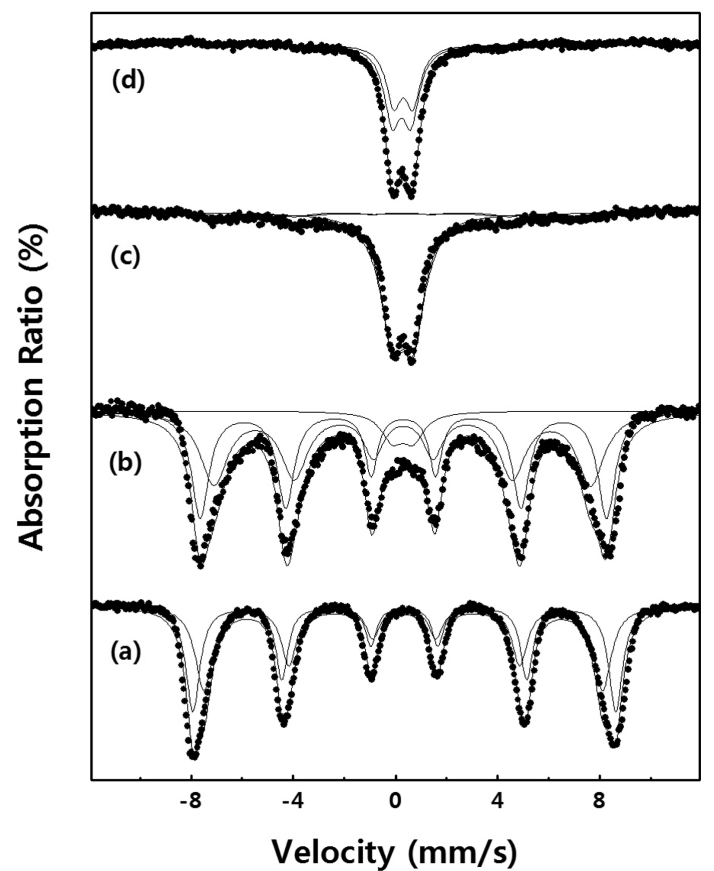

Fig. 4. Low temperature Mössbauer spectra of $\mathrm{MnFe}_{2} \mathrm{O}_{4}$ powder annealed at $523 \mathrm{~K}$; (a) $4.2 \mathrm{~K}$, (b) $50 \mathrm{~K}$, (c) $180 \mathrm{~K}$, and (d) $295 \mathrm{~K}$.

spectra can be explained to be the result of a variation in the magnetic phase that is dependent on the particle sizes. As shown for $\mathrm{Mn}_{1-2 \mathrm{x}} \mathrm{Zn}_{\mathrm{x}} \mathrm{Ni}_{\mathrm{x}} \mathrm{Fe}_{2} \mathrm{O}_{4}$ ferrite powders [14, 15], the doublet originates from the small particle size, and superparamagnetic properties are confirmed with the low-temperature Mössbauer spectra. As shown in Table 2, the values of the quadruple splitting $(Q S)$ and isomer shift $(I S)$ of the A and B sites exhibited a small change with the cobalt, zinc, and nickel-zinc substitution. However, the values of the magnetic hyperfine fields $\left(H_{h f}\right)$ of the cobalt-substituted sample increased some in the A and B sites, while the values of the magnetic hyperfine fields of zinc and nickel-zinc substituted samples decreased in the $\mathrm{A}$ and $\mathrm{B}$ sites. This variation in the values of the magnetic hyperfine fields indicates that the A-O-B superexchange

Table 2. Room temperature Mössbauer parameters of $\mathrm{MnFe}_{2} \mathrm{O}_{4}, \mathrm{Mn}_{0.8} \mathrm{Co}_{0.2} \mathrm{Fe}_{2} \mathrm{O}_{4}, \mathrm{Mn}_{0.8} \mathrm{Zn}_{0.2} \mathrm{Fe}_{2} \mathrm{O}_{4}$, and $\mathrm{Mn}_{0.8} \mathrm{Ni}_{0.1} \mathrm{Zn}_{0.1} \mathrm{Fe}_{2} \mathrm{O}_{4}$ ferrite powders annealed at $773 \mathrm{~K} . H_{h f}$ is the magnetic hyperfine field, $Q S$ is the quadrupole splitting, and $I S$ represent the isomer shift relative to metallic iron at room temperature.

\begin{tabular}{|c|c|c|c|c|c|c|}
\hline \multirow{2}{*}{ Sample } & \multicolumn{2}{|c|}{$H_{h f}(\mathrm{kOe})$} & \multicolumn{2}{|c|}{$Q S(\mathrm{~mm} / \mathrm{s})$} & \multicolumn{2}{|c|}{$I S(\mathrm{~mm} / \mathrm{s})$} \\
\hline & A site & B site & A site & B site & A site & B site \\
\hline $\mathrm{MnFe}_{2} \mathrm{O}_{4}$ & 481.0 & 441.1 & 0.00 & 0.01 & 0.30 & 0.40 \\
\hline $\mathrm{Mn}_{0.8} \mathrm{Co}_{0.2} \mathrm{Fe}_{2} \mathrm{O}_{4}$ & 483.0 & 447.0 & 0.00 & 0.01 & 0.31 & 0.39 \\
\hline $\mathrm{Mn}_{0.8} \mathrm{Zn}_{0.2} \mathrm{Fe}_{2} \mathrm{O}_{4}$ & 428.0 & 397.0 & 0.01 & 0.02 & 0.33 & 0.48 \\
\hline \multirow[t]{2}{*}{$\mathrm{Mn}_{0.8} \mathrm{Zn}_{0.1} \mathrm{Ni}_{0.1} \mathrm{Fe}_{2} \mathrm{O}_{4}$} & 480.8 & 433.5 & 0.00 & 0.01 & 0.26 & 0.45 \\
\hline & - & - & \multicolumn{2}{|c|}{1.15} & \multicolumn{2}{|c|}{0.31} \\
\hline
\end{tabular}




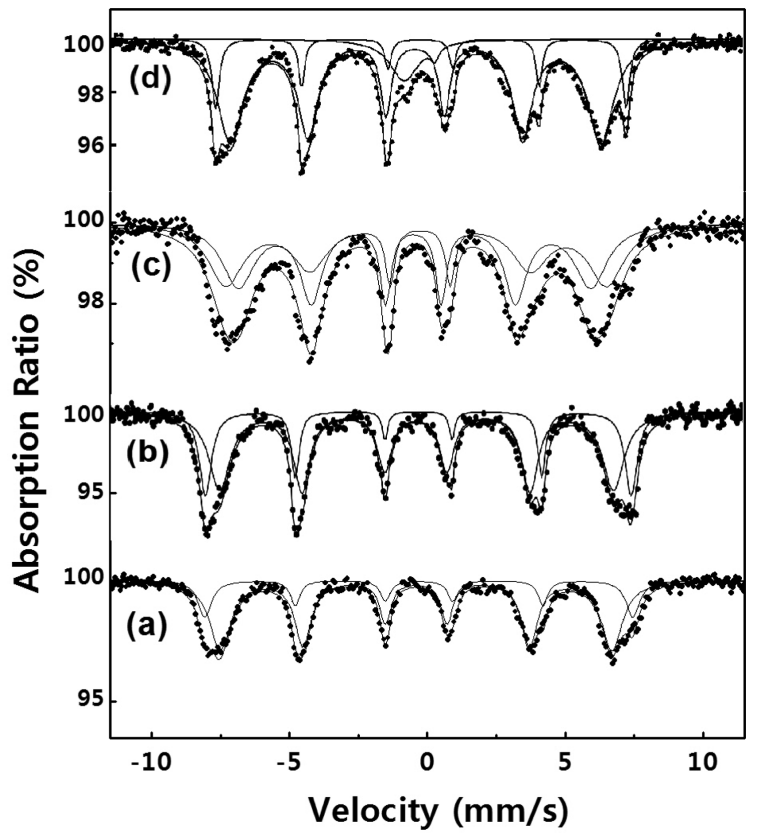

Fig. 5. Room temperature Mössbauer spectra of ferrite powders annealed at $773 \mathrm{~K}$ : (a) $\mathrm{MnFe}_{2} \mathrm{O}_{4}$, (b) $\mathrm{Mn}_{0.8} \mathrm{Co}_{0.2} \mathrm{Fe}_{2} \mathrm{O}_{4}$, (c) $\mathrm{Mn}_{0.8} \mathrm{Zn}_{0.2} \mathrm{Fe}_{2} \mathrm{O}_{4}$, and (d) $\mathrm{Mn}_{0.8} \mathrm{Ni}_{0.1} \mathrm{Zn}_{0.1} \mathrm{Fe}_{2} \mathrm{O}_{4}$.

interaction is strengthened with cobalt substitution in $\mathrm{Mn}_{0.8} \mathrm{Co}_{0.2} \mathrm{Fe}_{2} \mathrm{O}_{4}$, but those of the A-O-B superexchange interaction are weakened with the zinc and nickel-zinc substitution in $\mathrm{Mn}_{0.8} \mathrm{Zn}_{0.2} \mathrm{Fe}_{2} \mathrm{O}_{4}$ and $\mathrm{Mn}_{0.8} \mathrm{Ni}_{0.1} \mathrm{Zn}_{0.1} \mathrm{Fe}_{2} \mathrm{O}_{4}$. The variation in the A-O-B superexchange can also be explained through the use of a cation distribution. The cation distribution depends on many factors, such as the temperature, pressure, and composition [18, 19], as well as on the preparation method of compound. The Mössbauer absorption area ratio of the $\mathrm{A}$ and $\mathrm{B}$ sites, and the occupation preference sites for the substituted ions in a spinel structure, can both be used to determine the cation distribution of $\mathrm{MnFe}_{2} \mathrm{O}_{4}, \mathrm{Mn}_{0.8} \mathrm{Co}_{0.2} \mathrm{Fe}_{2} \mathrm{O}_{4}, \mathrm{Mn}_{0.8} \mathrm{Zn}_{0.2} \mathrm{Fe}_{2} \mathrm{O}_{4}$, and $\mathrm{Mn}_{0.8} \mathrm{Ni}_{0.1} \mathrm{Zn}_{0.1} \mathrm{Fe}_{2} \mathrm{O}_{4}$ as:

$\left(\mathrm{Mn}_{0.52} \mathrm{Fe}_{0.48}\right)\left[\mathrm{Mn}_{0.48} \mathrm{Fe}_{1.52}\right] \mathrm{O}_{4}$,

$\left(\mathrm{Mn}_{0.38} \mathrm{Fe}_{0.62}\right)\left[\mathrm{Mn}_{0.42} \mathrm{Co}_{0.20} \mathrm{Fe}_{1.38}\right] \mathrm{O}_{4}$,

$\left(\mathrm{Zn}_{0.20} \mathrm{Mn}_{0.25} \mathrm{Fe}_{0.55}\right)\left[\mathrm{Mn}_{0.55} \mathrm{Fe}_{1.45}\right] \mathrm{O}_{4}$,

$\left(\mathrm{Mn}_{0.61} \mathrm{Zn}_{0.10} \mathrm{Fe}_{0.29}\right)\left[\mathrm{Mn}_{0.19} \mathrm{Ni}_{0.10} \mathrm{Fe}_{1.71}\right] \mathrm{O}_{4}$.

This cation distribution equation is used to explain the superexchange interaction that is stronger with the cobalt substitution. An increase in cobalt ions results in a higher magnetic moment for the $\mathrm{Fe}^{3+}$ ions $\left(5 \mu_{B}\right)$ at the $\mathrm{A}$ sites, so the A-O-B superexchange becomes stronger in $\mathrm{Mn}_{0.8} \mathrm{Co}_{0.2} \mathrm{Fe}_{2} \mathrm{O}_{4}$. Meanwhile, an increase in $\mathrm{Zn}^{2+}\left(0 \mu_{B}\right)$ and $\mathrm{Ni}^{2+}\left(2 \mu_{B}\right)$ ions results in a lower magnetic moment at the A sites, so the A-O-B superexchange becomes weaker in $\mathrm{Mn}_{0.8} \mathrm{Zn}_{0.2} \mathrm{Fe}_{2} \mathrm{O}_{4}$, and $\mathrm{Mn}_{0.8} \mathrm{Ni}_{0.1} \mathrm{Zn}_{0.1} \mathrm{Fe}_{2} \mathrm{O}_{4}$.

The magnetic properties of the $\mathrm{MnFe}_{2} \mathrm{O}_{4}, \mathrm{Mn}_{0.8} \mathrm{Co}_{0.2} \mathrm{Fe}_{2} \mathrm{O}_{4}$,

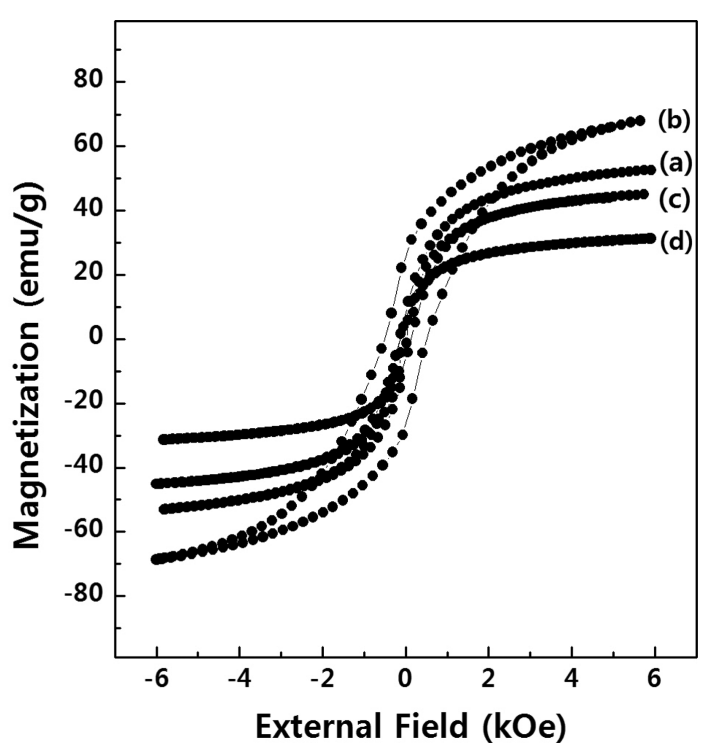

Fig. 6. Hysterisis curves of ferrite powders annealed at 773 $\mathrm{K}$ : (a) $\mathrm{MnFe}_{2} \mathrm{O}_{4}$, (b) $\mathrm{Mn}_{0.8} \mathrm{Co}_{0.2} \mathrm{Fe}_{2} \mathrm{O}_{4}$, (c) $\mathrm{Mn}_{0.8} \mathrm{Zn}_{0.2} \mathrm{Fe}_{2} \mathrm{O}_{4}$, and (d) $\mathrm{Mn}_{0.8} \mathrm{Ni}_{0.1} \mathrm{Zn}_{0.1} \mathrm{Fe}_{2} \mathrm{O}_{4}$.

$\mathrm{Mn}_{0.8} \mathrm{Zn}_{0.2} \mathrm{Fe}_{2} \mathrm{O}_{4}$, and $\mathrm{Mn}_{0.8} \mathrm{Ni}_{0.1} \mathrm{Zn}_{0.1} \mathrm{Fe}_{2} \mathrm{O}_{4}$ ferrite powders can be determined at room temperature via VSM. Figure 6 shows the hysteresis curves of the samples, revealing a typical soft ferrite pattern, and it shows the saturation magnetization and coercivity of the $\mathrm{MnFe}_{2} \mathrm{O}_{4}, \mathrm{Mn}_{0.8} \mathrm{Co}_{0.2^{-}}$ $\mathrm{Fe}_{2} \mathrm{O}_{4}, \mathrm{Mn}_{0.8} \mathrm{Zn}_{0.2} \mathrm{Fe}_{2} \mathrm{O}_{4}$ and $\mathrm{Mn}_{0.8} \mathrm{Ni}_{0.1} \mathrm{Zn}_{0.1} \mathrm{Fe}_{2} \mathrm{O}_{4}$ ferrite powders annealed at $773 \mathrm{~K}$. Relative to the saturation magnetization and coercivity of pure $\mathrm{MnFe}_{2} \mathrm{O}_{4}$, the Cosubstituted manganese ferrite powder, $\mathrm{Mn}_{0.8} \mathrm{Co}_{0.2} \mathrm{Fe}_{2} \mathrm{O}_{4}$, were larger, and the $\mathrm{Zn}$ and $\mathrm{Ni}-\mathrm{Zn}$ substituted manganese ferrite powders, $\mathrm{Mn}_{0.8} \mathrm{Zn}_{0.2} \mathrm{Fe}_{2} \mathrm{O}_{4}$ and $\mathrm{Mn}_{0.8} \mathrm{Ni}_{0.1} \mathrm{Zn}_{0.1} \mathrm{Fe}_{2} \mathrm{O}_{4}$, were smaller. These variations could thus be explained by using the cation distribution equations, particle sizes and magnetic moments of the substituted ions. $\mathrm{Mn}_{1-\mathrm{x}} \mathrm{Co}_{\mathrm{x}} \mathrm{Fe}_{2} \mathrm{O}_{4}$ ferrite powders have been reported to have a saturation magnetization that increased drastically with an increase in cobalt concentration up to $\mathrm{x}=0.6$ and then a decreased thereafter, and the coercivity increased up to $\mathrm{x}=0.8$ and then decreased [15]. The larger saturation magnetization $67.65 \mathrm{emu} / \mathrm{g}$ in $\mathrm{Mn}_{0.8} \mathrm{Co}_{0.2} \mathrm{Fe}_{2} \mathrm{O}_{4}$ than that $53.85 \mathrm{emu} / \mathrm{g}$ in $\mathrm{MnFe}_{2} \mathrm{O}_{4}$ could be qualitatively explained using the cation distribution equation and particle size effect of the substituted $\mathrm{Co}$ ions. The Mössbauer absorption area in $\mathrm{Mn}_{0.8} \mathrm{Co}_{0.2} \mathrm{Fe}_{2} \mathrm{O}_{4}$ shows that the octahedral $\mathrm{Fe}$ and $\mathrm{Mn}$ ions decreased as the Co ions increased. The substitution of the $\mathrm{Mn}^{2+}\left(5 \mu_{B}\right)$ and $\mathrm{Fe}^{3+}\left(5 \mu_{B}\right)$ with a greater magnetic moment ions by the $\mathrm{Co}^{2+}\left(3 \mu_{B}\right)$ with lesser magnetic moment ions could be expected to reduce the saturation magnetization. Therefore, the results of this work do not support this explanation. However, the XRD and SEM 
results show that the particles increased in size with cobalt ion substitution, and this could have led to an increase in the saturation magnetization and coercivity. Similar results were obtained in Mn-Co thin film and $\mathrm{Co}_{0.5} \mathrm{Mn}_{0.5} \mathrm{Fe}_{2} \mathrm{O}_{4}$ nanoparticles $[20,21]$. In the $\mathrm{Mn}_{0.8} \mathrm{Zn}_{0.2^{-}}$ $\mathrm{Fe}_{2} \mathrm{O}_{4}$ ferrite powder, the value of the saturation magnetization $41.06 \mathrm{emu} / \mathrm{g}$ is smaller than that of pure $\mathrm{MnFe}_{2} \mathrm{O}_{4}$, and this decrease can be explained by the substitution of nonmagnetic $\mathrm{Zn}^{2+}\left(0 \mu_{B}\right)$ ions substituted for $\mathrm{Mn}^{2+}\left(5 \mu_{B}\right)$ ions with a larger magnetic moment. From the cation distribution equation, the $\mathrm{Fe}^{3+}\left(5 \mu_{B}\right)$ distributed between the $\mathrm{A}$ and $\mathrm{B}$ sites remain almost unchanged, so the saturation magnetization value of the $\mathrm{Mn}_{0.8} \mathrm{Zn}_{0.2} \mathrm{Fe}_{2} \mathrm{O}_{4}$ ferrites should smaller. The coercivity value also decreases rapidly from $124.6 \mathrm{Oe}$ in $\mathrm{MnFe}_{2} \mathrm{O}_{4}$ to $92.2 \mathrm{Oe}$ in $\mathrm{Mn}_{0.8^{-}}$ $\mathrm{Zn}_{0.2} \mathrm{Fe}_{2} \mathrm{O}_{4}$ ferrite powder as the zinc substitution. The coercivity in polycrystalline ferrites is well known to be strongly dependent on the magneto crystalline anisotropy constant and the grain size. In the $\mathrm{Mn}_{0.8} \mathrm{Zn}_{0.2} \mathrm{Fe}_{2} \mathrm{O}_{4}$ ferrite powder, the grain size does not change abruptly, so the main effect on the coercivity decrease may be a decrease in the magneto crystalline anisotropy constant for $\mathrm{Zn}^{2+}$, with respect to that of $\mathrm{Mn}^{2+}$. This result indicates that, the $\mathrm{Mn}_{0.8} \mathrm{Zn}_{0.2} \mathrm{Fe}_{2} \mathrm{O}_{4}$ ferrite shows a lower saturation magnetization and coercivity than pure $\mathrm{MnFe}_{2} \mathrm{O}_{4}$. In the $\mathrm{Mn}_{0.8} \mathrm{Ni}_{0.1} \mathrm{Zn}_{0.1} \mathrm{Fe}_{2} \mathrm{O}_{4}$ ferrite powder, the saturation magnetization is somewhat smaller $(36.55 \mathrm{emu} / \mathrm{g})$ than that of pure $\mathrm{Fe}_{2} \mathrm{O}_{4}(53.85 \mathrm{emu} / \mathrm{g})$. This variation could be qualitatively explained by the superparamagnetic phase that is dependent on the particle size and the magnetic moment of the substituted $\mathrm{Ni}$ and $\mathrm{Zn}$ ions. The Mössbauer absorption area indicates that the doublet is a result of the superparamagnetic phase in $\mathrm{Mn}_{0.8} \mathrm{Ni}_{0.1} \mathrm{Zn}_{0.1} \mathrm{Fe}_{2} \mathrm{O}_{4}$, and this could produce high values for the saturation magnetization. However the replacement of ions with a larger magnetic moment $\left(\mathrm{Fe}^{3+}=5 \mu_{B}, \mathrm{Mn}^{3+}=5 \mu_{B}\right)$ by ions with a smaller magnetic moment $\left(\mathrm{Ni}^{2+}=3 \mu_{B}, \mathrm{Zn}^{2+}=0 \mu_{B}\right)$ could produce low values for the saturation magnetization. As a result of these two effects, the saturation magnetization decreases slightly with $\mathrm{Ni}$ and $\mathrm{Zn}$ substitution [19], and the coercivity $\left(105.8 \mathrm{Oe}\right.$ ) of the $\mathrm{Mn}_{0.8} \mathrm{Ni}_{0.1} \mathrm{Zn}_{0.1} \mathrm{Fe}_{2} \mathrm{O}_{4}$ ferrite powder is smaller than that of pure $\mathrm{MnFe}_{2} \mathrm{O}_{4}$, which could also be related to the particle size $[17,19]$. The superparamagnetic phase resulting from the smaller particle size changed to a ferrimagnetic phase, as confirmed by the Mössbauer spectra. These results reflect a relatively low coercivity when compared to the value for $\mathrm{MnFe}_{2} \mathrm{O}_{4}$. Similar results were obtained for the $\mathrm{Mn}_{0.6} \mathrm{Zn}_{0.4} \mathrm{Fe}_{2} \mathrm{O}_{4}$, and $\mathrm{Mn}_{0.6} \mathrm{Ni}_{0.4} \mathrm{Fe}_{2} \mathrm{O}_{4}$ ferrite powders [15, 22].

\section{Conclusion}

Cobalt-, zinc-, and nickel-zinc-substituted nano-size manganese ferrite powders, $\mathrm{MnFe}_{2} \mathrm{O}_{4}, \mathrm{Mn}_{0.8} \mathrm{Co}_{0.2} \mathrm{Fe}_{2} \mathrm{O}_{4}$, $\mathrm{Mn}_{0.8} \mathrm{Zn}_{0.2} \mathrm{Fe}_{2} \mathrm{O}_{4}$ and $\mathrm{Mn}_{0.8} \mathrm{Ni}_{0.1} \mathrm{Zn}_{0.1} \mathrm{Fe}_{2} \mathrm{O}_{4}$, were fabricated via the sol-gel method, and their crystallographic and magnetic properties were compared. The $\mathrm{MnFe}_{2} \mathrm{O}_{4}$ ferrite powder annealed at temperatures above $523 \mathrm{~K}$ exhibited the presence of a spinel structure, and the particle size increased as the annealing temperature increased. All ferrite samples annealed at $773 \mathrm{~K}$ showed a single spinel structure, with lattice constants that decreased and particle size that increased with the substitution of $\mathrm{MnFe}_{2} \mathrm{O}_{4}$ ferrites with $\mathrm{Co}, \mathrm{Zn}$, and Ni-Zn. The Mössbauer spectrum of the $\mathrm{MnFe}_{2} \mathrm{O}_{4}$ ferrite powder annealed at $523 \mathrm{~K}$ showed only a doublet due to its superparamagnetic phase. The Mössbauer spectra of $\mathrm{MnFe}_{2} \mathrm{O}_{4}, \mathrm{Mn}_{0.8} \mathrm{Co}_{0.2} \mathrm{Fe}_{2} \mathrm{O}_{4}, \mathrm{Mn}_{0.8^{-}}$ $\mathrm{Zn}_{0.2} \mathrm{Fe}_{2} \mathrm{O}_{4}$ ferrite powders annealed at $773 \mathrm{~K}$ could be fitted as the superposition of two Zeeman sextets due to the $\mathrm{A}$ and $\mathrm{B}$ sites of the $\mathrm{Fe}^{3+}$ ions. However, the Mössbauer spectrum of $\mathrm{Mn}_{0.8} \mathrm{Ni}_{0.1} \mathrm{Zn}_{0.1} \mathrm{Fe}_{2} \mathrm{O}_{4}$ consisted of two Zeeman sextets and one quadrupole doublet resulting from the ferrimagnetic and paramagnetic behavior. The area ratio of the Mössbauer spectra can be used to decide the cation distribution of $\mathrm{MnFe}_{2} \mathrm{O}_{4}, \mathrm{Mn}_{0.8} \mathrm{Co}_{0.2} \mathrm{Fe}_{2} \mathrm{O}_{4}$, $\mathrm{Mn}_{0.8} \mathrm{Zn}_{0.2} \mathrm{Fe}_{2} \mathrm{O}_{4}$ and $\mathrm{Mn}_{0.8} \mathrm{Ni}_{0.1} \mathrm{Zn}_{0.1} \mathrm{Fe}_{2} \mathrm{O}_{4}$ as $\left(\mathrm{Mn}_{0.52} \mathrm{Fe}_{0.48}\right)$ $\left[\mathrm{Mn}_{0.48} \mathrm{Fe}_{1.52}\right] \mathrm{O}_{4},\left(\mathrm{Mn}_{0.38} \mathrm{Fe}_{0.62}\right)\left[\mathrm{Mn}_{0.42} \mathrm{Co}_{0.20} \mathrm{Fe}_{1.38}\right] \mathrm{O}_{4},\left(\mathrm{Zn}_{0.20^{-}}\right.$ $\left.\mathrm{Mn}_{0.25} \mathrm{Fe}_{0.55}\right)\left[\mathrm{Mn}_{0.55} \mathrm{Fe}_{1.45}\right] \mathrm{O}_{4},\left(\mathrm{Mn}_{0.61} \mathrm{Zn}_{0.10} \mathrm{Fe}_{0.29}\right)\left[\mathrm{Mn}_{0.19} \mathrm{Ni}_{0.10^{-}}\right.$ $\left.\mathrm{Fe}_{1.71}\right] \mathrm{O}_{4}$.

We also explained the variation in the Mössbauer parameters using this cation distribution equation, superexchange interaction and particle size. Relative to pure $\mathrm{MnFe}_{2} \mathrm{O}_{4}$, the saturation magnetizations and coercivities are larger in the $\mathrm{Mn}_{0.8} \mathrm{Co}_{0.2} \mathrm{Fe}_{2} \mathrm{O}_{4}$ and are smaller in $\mathrm{Mn}_{0.8} \mathrm{Zn}_{0.2} \mathrm{Fe}_{2} \mathrm{O}_{4}$ and $\mathrm{Mn}_{0.8} \mathrm{Ni}_{0.1} \mathrm{Zn}_{0.1} \mathrm{Fe}_{2} \mathrm{O}_{4}$. These variations could be explained by using the site distribution equations, particle sizes and magnetic moments of the substituted ions.

\section{References}

[1] A. Goldman, Modern Ferrite Technology, Van Nostrand Reinhold, New York (1990) p. 217.

[2] J. M. Hastings and L. M. Corliss, Phys. Rev. 104, 328 (1965).

[3] A. S. Albaguergye, J. D. Ardisson, and W. A. A. Macedo, J. Appl. Phys. 87, 4352 (2000).

[4] N. N. Greenwood and T. C. Gibb, Mössbauer spectroscopy, Chapman and Hall Ltd. London (1971) p. 261-266.

[5] V. Blasko, V. Petkov, V. Rusanov, Ll. M. Martinez, B. Martinez, J. S. Muñoz, and M. Mikhove, J. Magn. Magn. 
Mater. 162, 331 (1996).

[6] J. C. Ho, H. Hamdeh, Y. Chen, S. Lin, Y. Yao, R. Willey, and S. Oliver, Phys. Rev. B 52, 10122 (1995).

[7] F. J. Burghart, W. Potzel, G. M. Kalvius, E. Schreier, G. Grosse, D. R. Noakes, W. Schäfer, W. Kockelmann, S. J. Campbell, W. A. Kaczmarek, A. Martin, and M. K. Krause, Physica B 289, 286 (2000).

[8] A. H. Morrish and K. Haneda, J. Appl. Phys. 52, 2497 (1981).

[9] K. Oda, T. Yoshio, K. Hirata, K. O. Oka, and K. Takabashi, J. Jpn. Soc., Powder Powder Metal. 29, 170 (1982).

[10] V. K. Sankaranarayana, Q. A. Pankhurst, D. P. E. Dickson, and C. E. Johson, J. Magn. Magn. Mater. 125, 199 (1993).

[11] W. O. Choi, J. G. Lee, B. S. Kang, and K. P. Chae, J. Magn. 19, 59 (2014).

[12] W. O. Choi, W. H. Kwon, K. P. Chae, and Y. B. Lee, J. Magn. 21, 40 (2016).
[13] C. G. Whinfrey, D. W. Eckort, and A. Tauber, J. Am. Chem. Soc. 82, 2695 (1960).

[14] B. D. Cullity, Elements of X-Ray Diffraction, Addition Wesley Co. (1978) p. 102.

[15] W. H. Kwon, J. Y. Kang, J. G. Lee, S. W. Lee, and K. P. Chae, J. Magn. 15, 159 (2010).

[16] J. Y. Kang, W. H. Kwon, S. W. Lee, B. S. Kang, and K. P. Chae, J. Korean Phys. Soc. 60, 795 (2012).

[17] W. O. Choi, W. H. Kwon, J. G. Lee, B. S. Kang, and K. P. Chae, J. Korean Phys. Soc. 61, 1812 (2012).

[18] R. K. Datta and B. Roy, J. Amer. Coram. Soc. 50, 578 (1967).

[19] M. Z. Schmalzrifd, J. Phys. Chem. 28, 203 (1961).

[20] K. J. Kim, H. K. Kim, Y. R. Park, and J. Y. Park, J. Korean Magn. Soc. 16, 23 (2006).

[21] M. K. Shobana, S. Sankar, and V. Rayendran, Material Chem. Phys. 113, 10 (2009).

[22] W. H. Kwon, J. G. Lee, Y. B. Lee, and K. P. Chae, J. Magn. 16, 1 (2011). 